\title{
Innovation Strategy of College Students' Entrepreneurship Education in Modern Times
}

\author{
Yun Sun \\ Oxbridge College, Kunming University of Science and Technology, Kunming, 650106, China
}

Keywords: University, College students' entrepreneurship education, Innovation strategy

\begin{abstract}
Entrepreneurship education plays an important role in the higher education and its effect can't be ignored . However, in practice, the business education and teachers' teaching strategies are not changed with the social changes, which leads to the current college entrepreneurship education does not conform to the trend of social development, it can not play its role effective . This paper analyzes the innovation strategy of College Students' Entrepreneurship Education in modern times, and expounds their own suggestions, hoping to provide a little help for college students' entrepreneurship education.
\end{abstract}

\section{Introduction}

At present, the number of college students venture has increased, but the number of successful people is still very few, this situation has seriously hit the enthusiasm of College Students' initiative. In order to stimulate the enthusiasm of students, colleges and universities must enhance the importance of entrepreneurship education. Colleges and universities should help students to grasp more entrepreneurial knowledge and achieve good results for students to start a business to get good results.There are many problems in the process of carrying out entrepreneurship education in Colleges and universities. These problems result in the role of entrepreneurship education. Therefore, how to solve the problems in entrepreneurship education has become the focus of attention.

\section{Current era of college students innovation and entrepreneurship teaching status and problems}

\section{Current situation of College Students' Entrepreneurship Education}

In the last few years, we have made great efforts in the teaching of College Students' Entrepreneurship Education in order to achieve better teaching effect. However, as a whole, because of the relatively late start of College Students' Entrepreneurship Education in our country, it has a lot of problems, so there are still a lot of problems in the business education. Moreover, the current college students' entrepreneurship education is not connected the social development, nor take full account of the actual development of colleges and universities. The development of entrepreneurship education in this case, does not meet the current social development trend [1]. In the face of this situation, it is necessary to conduct a thorough study of the college students' entrepreneurship education and to make innovations in it.

\section{The problems existed in college students' Entrepreneurship Education}

The main purpose is to encourage college students to start their own business, and to lay a good foundation for college students, so as to stimulate the enthusiasm of the current college students' entrepreneurship, and reduce the pressure on social employment. In the course of the actual teaching of the University, the influence of many factors, which leads to many problems in the teaching .This paper carries on the concrete analysis to these questions, the content is as follows:

First,Without building a sound system of entrepreneurship education curriculum and teaching positioning is not accurate. In the process of carrying out entrepreneurship education in Colleges and universities, this teaching content as a part of "College Students' career planning", in the course of teaching, teachers pay more attention to the students' career guidance, and neglect the business teaching.Due to the limited teaching experience, some teachers are unable to carry out and practice activities related to Teaching Entrepreneurship, leading to the relevant content of the practice teachers skated over, without any detailed explanation, which make many students can not master the 
practical skills and entrepreneurship. At the same time, teach division of this kind of teaching behavior is also a serious blow to the enthusiasm of the students, the students cannot pass through entrepreneurship education and gets more entrepreneurial practice - related knowledge, in fact, practical ability cannot be cultured. As some colleges and universities don't have accurate positioning of the business and business practices ,they pay attention to the teaching of practical skills training, but neglect the cultivation of students' innovative awareness, ultimately lead to the low level of students' entrepreneurship.

Second, Being short of teachers in entrepreneurship education. College Students' entrepreneurship education has the characteristics of strong practicality and strong practicality. This characteristics of the university education requires teachers with high comprehensive quality and teaching experience, connecting the practical teaching and theoretical teaching effectively . But in practical teaching, the responsibility of the employment guidance center is the counselors or teachers.However, counselors and teachers do not have the ability to carry out entrepreneurship teaching, they are in the process of teaching. Although it can do a good job of theoretical knowledge, its interpretation is only to stay on the surface of the material, there is no substantive significance, and this part of the business practice of the case is not much, there is no way to explain to students with valuable experience. It can be seen that the current college students' entrepreneurship teaching is relatively scarce, and the power is weak, these teachers are not able to meet the needs of the current college students, which can not meet the needs of the current college students.

Third, Being short of entrepreneurial environment in the campus, the students' enthusiasm is not high. In the course of undertaking the undertaking teaching, universities and colleges only pay attention to the theoretical knowledge, neglect the cultivation of students' pioneering thinking and ability, and provide the support of the students' entrepreneurship, equipment, capital and time. In addition, colleges and universities to carry out the activities of the business is relatively simple, and the design is rough, through the participation of students and can not get more help. For example, colleges and universities to carry out the business forum, competitions and other activities without any new ideas, and its content is similar, so that it was impossible to mobilize students to participate in the enthusiasm, students participate in activities also not to venture to provide substantial help, this situation leads to colleges and universities to carry out the entrepreneurship education no role to play, did not help the students after.

\section{The innovation strategy of College Students' Entrepreneurship Education in modern times}

\section{To build a sound innovation and entrepreneurship education system}

It is a very effective measure to build a perfect system of innovation and entrepreneurship education in Colleges and universities. At the same time, the university should also determine the status of innovation and entrepreneurship education, and to cultivate the innovative spirit of students and improve the practical ability of students as the purpose of education in Colleges and universities. Teachers in the choice of teaching contents, should select related entrepreneurial education courses, and law, entrepreneurial marketing, business management and economics, into which the contents, so as to broaden the students knowledge, for students to start their own businesses to lay a solid theoretical basis.

\section{On the campus to create a good cultural atmosphere}

Innovation and entrepreneurship education is not only the responsibility of the employment guidance department, but also with other functional departments have a close contact.Colleges and universities should allow all departments to recognize their responsibilities, realizing the cooperation of various departments, and carry out innovation and entrepreneurship education.Create a good business culture atmosphere, and enhance the entrepreneurial enthusiasm of college students to ensure the orderly development of College students. Colleges and universities should start from the ideological aspect, so that all the college teachers are aware of the importance of innovation and entrepreneurship education. So as to provide convenience for innovation and entrepreneurship education in the practical work, at the same time, the university should also increase the investment in innovation and entrepreneurship education, to build a high-quality teachers, funds and equipment, 
etc., to provide a strong guarantee for innovation and entrepreneurship education. In addition, colleges and universities can also be in the campus propaganda column, newspapers and periodicals on the promotion of the country for college students to develop preferential policies, through the theme activities, academic exchanges and competitions and other ways for students to create a good entrepreneurial culture atmosphere, to stimulate students interest in innovation and entrepreneurship education, mobilize the enthusiasm of students, and give full play to the role of innovation and entrepreneurship, to lay a good foundation for the future of College students.

Building high quality teachers team and improving the level of innovation and entrepreneurship education in Colleges and Universities

Teachers are the main body of innovation and entrepreneurship education, teachers' teaching level has a direct impact on the effect of teaching innovation and entrepreneurship teaching. In view of this situation, colleges and universities should set up a high quality teachers team, so as to improve the efficiency of innovation and entrepreneurship education. Teachers are generally employed in innovation and entrepreneurship education. The teachers are limited, it is difficult to play the role of innovation and entrepreneurship, therefore, colleges and universities should actively encourage professional teachers to join in the innovation and entrepreneurship education, and thus improve the overall level of teachers. On the other hand, colleges and universities should set up a sound teaching assessment, professional title evaluation system, in the system of specific requirements and standards, so that teachers can feel the pressure, in the daily life of autonomous learning, and constantly improve their knowledge level [4]. Colleges and universities can work together with enterprises to carry out innovation and entrepreneurship education, for example, the university can hire successful entrepreneurs part-time guidance teachers, this part of the part-time teachers in the business with rich experience, in the process of teaching can explain more practical problems, and the theory of knowledge and life practice better linked together, and to improve students' mastery level, at the same time, these part-time teachers also can provide certain guidance for teachers to make up for the shortcomings in teaching.

Enriching the carrier of innovation and entrepreneurship, improving the enthusiasm of College Students' Entrepreneurship

Innovation and entrepreneurship education in the classroom is not enough, the university should also be aimed at innovation and Entrepreneurship Education held a number of colorful activities, broaden the carrier of innovation and entrepreneurship, improve students' initiative. Before the activity, we can understand the psychological needs of students through questionnaire survey, and then according to the students' needs to design a specific activity plan, in the design process, we should pay attention to the activities of innovation, try to avoid the same activities and other activities, to provide students with innovative ideas and innovative entrepreneurship teaching activities. Universities to carry out activities, not only to stimulate students' interest in innovation and entrepreneurship teaching, but also to develop students' risk, innovation, competition and team awareness, for the students to carry out their own business to lay a solid foundation.

\section{Strengthen the construction of innovation and entrepreneurship community and build bridges of communication}

College students innovation and entrepreneurship community is the main position of innovation and entrepreneurship education of college students, and has important influence on the innovation and entrepreneurship education in Colleges and universities. Therefore, colleges and universities should strengthen the construction of innovation and entrepreneurship community, building a bridge of communication. On the basis of the following aspects: first, to guide the community, teachers should enhance the degree of attention to the community, to do a good job in the management of community. Second, we should establish a sound corporate management system, staff can get better results, in addition, under the constraints of scientific and reasonable system, but also can give full play to their own management ability [5]. Business training should include the following elements, such as human resources, entrepreneurial psychological counseling, etc.. In the community, students can freely, and the other students are friendly exchanges, the thinking of the collision in the exchange 
process will produce, so as to improve the students' awareness of innovation education, the students better learning innovation and entrepreneurship knowledge to provide a little help for.

\section{Establishing innovative teaching base for students to create innovative entrepreneurial practice platform}

The innovation and entrepreneurship education in Colleges and universities has the characteristics of strong practicality. In the face of this situation, the university should set up innovative teaching bases, and provide a platform for students to carry out innovative and entrepreneurial education. Colleges and universities should set up the demand of innovation and entrepreneurship education, the establishment of the business park, the business incubation and training base, and then provide an effective exchange platform for the college students' entrepreneurship. At the same time, colleges and universities can work together to carry out innovation and entrepreneurship teaching, the university can work together with enterprises to set up a platform for innovation and entrepreneurship education. The practice base in the school will become the main body of the teachers.

\section{Concluding remarks}

To sum up, there are still some problems in the current colleges and universities to carry out the innovation and entrepreneurship teaching , the existence of these problems dealt a severe blow to the enthusiasm of the students to start their own businesses.Facing such problems, colleges and universities to make innovation and entrepreneurship teaching, you should teach on the basis of the innovation and entrepreneurship, take effective measures to solve the problem, change the concept of teaching, to strengthen the research and exploration, to establish a long-term mechanism of sound, and for colleges and universities to better carry out innovation and entrepreneurship teaching help, to cultivate more innovative talents.

\section{References}

[1] Shang Yingmei, Fang Lin, Ma Chenglong. Exploring and analysis of the status of practice of entrepreneurship education in Colleges and universities. Modern development (Higher Education Research), 2013 (1): 43-47.

[2] Zheng Jianhui. Employment of college students entrepreneurship education based on the perspective of employment. Continuing education research, 2014 (6): 97-99.

[3] Cai Chunchi. The development of entrepreneurship education in China: the development of entrepreneurship education in Colleges and Universities: the development trend of entrepreneurship. Education in Colleges and Universities. 2012 (1): 86-89.

[4] Li Zhanping, Wang Xianming, Zhao Yongxin et al. New mode of innovation and entrepreneurship education for College Students -- A Study on the model of the cloud platform for the national education administration of education. Journal of the National Institute of Educational Administration, 2012 (11): 12-15.

[5] Wu Wei. Multidimensional subjectivity from the perspective of entrepreneurship education of college students facing the predicament and mechanism construction. Modern education and Management, 2015 (3): 115-118. 